From the Field

\title{
The Italian legal clinics movement: Data and prospects
}

Clelia Bartoli, Università di Palermo, Italy; European Network for Clinical Legal Education, (ENCLE)

\section{cleliabartoli@libero.it}

\section{THE INQUIRY}

It is not more than 5 years since legal clinics were founded in Italian Universities: a very recent history indeed and similar to that of other Western European countries ${ }^{1}$. I will try to explain this through some data collected by an inquiry that I ran in order to have a more detailed map of this phenomena and to conjecture its future evolution ${ }^{2}$.

The survey I submitted to the Italian clinics is composed mainly of multiple choice questions with some open-ended questions. It is divided into six sections: a) general description of the clinic; b) economic profile; c) the educational issue; d) areas of interventions and types of clients; e) the network; f) its social impact.

The survey was sent to all directors of Italian Law Departments with a letter where they were requested to readdress it to the head of the legal clinic, where these existed. 21 clinics, placed in 13 different towns, have completed the survey: among them are both established and fledgling clinics (fig. 1-2-3). There may be some facts that escaped my enquiry. However, I believe that I can offer a suitable overview of the situation in the country $^{3}$. Anyway we must consider this as a state of affairs in ferment, which is highly changeable.

\footnotetext{
${ }^{1}$ U. Stege, Evidence of Successes and Challenges in Clinical Legal Education in Europe, in press.

${ }^{2}$ I would thank Marzia Casolari and Ulrich Stege very much for their important support and wise suggestions. This research is part of a larger inquiry on European Legal Clinics, conducted with the ENCLE collaboration. It has been required and sponsored by Cécile Kyenge, member of the European Parliament and former Italian Minister for Integration.

${ }^{3}$ Last updating: May 2015. As far as I know what remains outside of my inquiry is: a) the branch of "L'altro diritto" in Emilia Romagna, but its answers would be almost the same as the Tuscany headquarters and b) a legal clinic with six different specializations in "Università Cattolica di Milano" started at the end of 2014, it is hosted in a private university unlike the others I recorded. Not all agree to define that a clinic because it proposes mainly simulations based on real cases already closed, so the students do not come in contact with live clients; c) I am also informed the law departments of Bologna and Catania are planning to open new clinics.
} 
In the following paragraphs I will present the data inquiry and I will try to explain the process of establishing the Italian movement for legal education, its options and challenges.

It is worth pointing out why I use the term "movement". What is going on in Italy, and I think elsewhere, is not simply the proliferation of single clinics, but the emergence of a new wave in academia. On the basis of the clinician idea and history, Italian scholars involved in this process are formulating a different way to teach law, and a different view of law too. I think it is not by chance that many of the pioneers of clinical education have a philosophical background or a highly speculative approach.

It would seem strange that such a practical teaching style is promoted by the most theoretical part of the law faculty staff. The reason for this is probably that the clinician approach needs a paradigm shift through a more realistic, critical and socially committed conception of law.

\section{THE ITALIAN CLINICS}

Clinics at least four-years-old are located in a few towns (Brescia, Roma, Torino). In Bergamo, Teramo, Perugia and Verona clinics have existed for two or three years.

We have to note the particular case of "L'altro diritto". This is an association founded in the University of Florence about twenty years ago and, even though it never called itself a "legal clinic" it has always performed in a similar way. At the beginning, the students were involved in providing legal aid for the detainees of some Tuscan prisons. In addition, over time, "L'altro diritto" has developed a large number of activities and projects in favour of migrants, refugees, Romas and every kind of exploited and excluded people in different towns of Central Italy, where hundreds of law students and other volunteers are engaged. This association is also a documentation centre, legislation observatory and it produces drafts for social policies. Recently it has opened a Sicilian branch connected with the Human Rights PhD of the University of Palermo. After many years of informal clinician work, "L'altro diritto" has decided to give to a part of its pursuits the status of legal clinic. I have chosen to enclose this association in my survey, not only because 
"L'altro diritto" was acting as a law clinic, but because it plays an important role in the Italian movement for clinical education thanks to its experience and extent.

Fig. 1 - Established clinics

\begin{tabular}{|c|c|c|c|}
\hline Name & age & University department & Staff \\
\hline $\begin{array}{l}\text { L'Altro Diritto: Centro di } \\
\text { documentazione carcere, devianza e } \\
\text { marginalità }\end{array}$ & 19 & Dipartimento di Scienze Giuridiche, Firenze & 100 \\
\hline Clinica Legale, Univ. di Brescia & 5 & $\begin{array}{l}\text { Univ. degli Studi di Brescia Dipartimento di } \\
\text { Giurisprudenza }\end{array}$ & 30 \\
\hline Clinica legale I e II, Univ. di Brescia & 5 & $\begin{array}{l}\text { Univ. degli Studi di Brescia Dipartimento di } \\
\text { Giurisprudenza }\end{array}$ & 15 \\
\hline $\begin{array}{l}\text { Clinica del diritto dell'immigrazione e } \\
\text { della cittadinanza }\end{array}$ & 5 & Dipartimento di Giurisprudenza, Università Roma TRE & 10 \\
\hline $\begin{array}{l}\text { Human Rights and Migration Law } \\
\text { Clinic }\end{array}$ & 4 & $\begin{array}{l}\text { International University College of Turin, DG } \\
\text { dell'Università di Torino, Università del Piemonte } \\
\text { orientale }\end{array}$ & 15 \\
\hline Clinica legale in diritto dei minori & 3 & Dipartimento di Giurisprudenza, Univ. Roma TRE & 6 \\
\hline Clinica Legale di Diritto del lavoro & 3 & Università degli studi di Teramo & 4 \\
\hline Diritto ambientale & 3 & Università degli studi di Bergamo & 2 \\
\hline Clinica legale penitenziaria & 3 & Università di Perugia, Dipartimento di Giurisprudenza & 15 \\
\hline $\begin{array}{l}\text { Clinica legale in diritto dei } \\
\text { risparmiatori }\end{array}$ & 2 & Dipartimento di Giurisprudenza, Univ. Roma TRE & 2 \\
\hline Salute, ambiente e territorio & 2 & Dipartimento di Giurisprudenza, Univ. di Perugia & 9 \\
\hline Clinica Legale Verona & 2 & Diparti. di Scienze Giuridiche, Università di Verona & 8 \\
\hline Carcere e diritti & 2 & Dipartimento di Giurisprudenza, Univ. di Torino & 6 \\
\hline Persone e famiglia & 1 & Dipartimento di Giurisprudenza, Univ. di Torino & 1 \\
\hline
\end{tabular}

Fig. 2 - Fledgeling clinics

\begin{tabular}{|llc|}
\hline \multicolumn{1}{|c}{ Name } & \multicolumn{1}{c|}{ University department } & Staff \\
\hline Clinica Legale per i diritti umani & DIGISPO Palermo & 10 \\
\hline $\begin{array}{l}\text { Spazi violenti. L'empowerment e accesso } \\
\text { al diritto delle persone svantaggiate }\end{array}$ & Dipartimento di Giurisprudenza, Università di Torino & 5 \\
\hline Clinica legale di diritto penale & $\begin{array}{l}\text { Dip. Cesare Beccaria - sezione di scienze penalistiche. } \\
\text { Università di Milano }\end{array}$ & 8 \\
\hline Da definire & Dipartimento Jonico di Studi Giuridici ed Economici & 30 \\
\hline $\begin{array}{l}\text { Clinica legale } \\
\text { "Federico II" }\end{array}$ & Dipartimento di Giurisprudenza, Federico II, Napoli & -- \\
\hline Accesso alla giustizia & Dipartimento di Giurisprudenza dell'Università di & -- \\
\hline Da definire & Sassari & 5 \\
\hline
\end{tabular}


As can be seen from the map (fig. 3), the concentration of clinics is more in the Centre and in the North of Italy, but some clinician projects are growing in the South too.

Fig. 3 -Territorial distribution

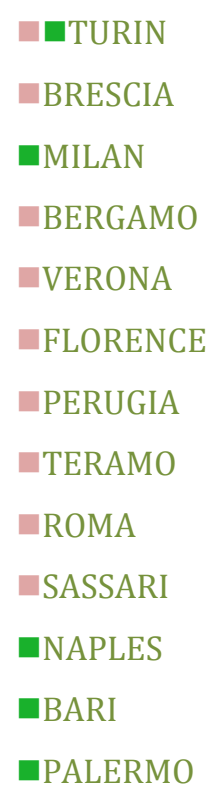

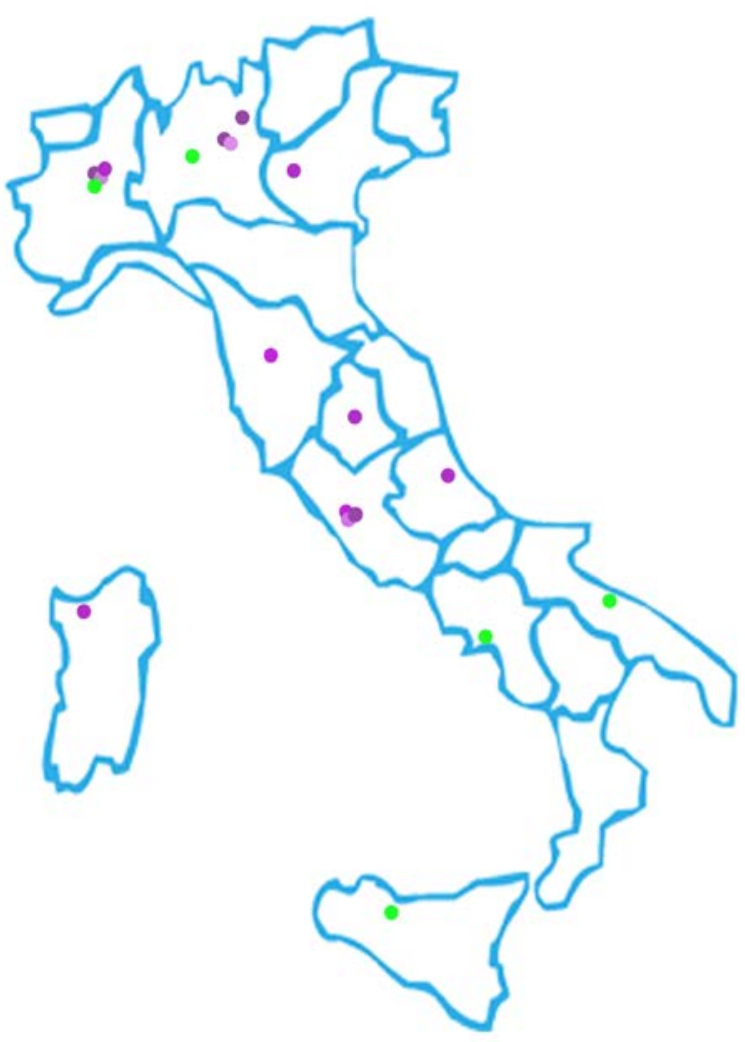

Established clinics $\quad$ Fledgling clinics

\section{ECONOMIC PROFILES}

Money is not the brightest aspect of this story. Italian clinics work with extremely low budgets. $35 \%$ of them assert that their coffers are empty (of course among these there are the fledgling clinics seeking grants to start), $24 \%$ have an annual income under 10,000 €. The remaining $29 \%$ have a budget around $15,000 €$ or a little more, and in any case there is not a clinic performing with $40,000 €$ or more per year (fig. 4). 
Fig. 4 - Budget

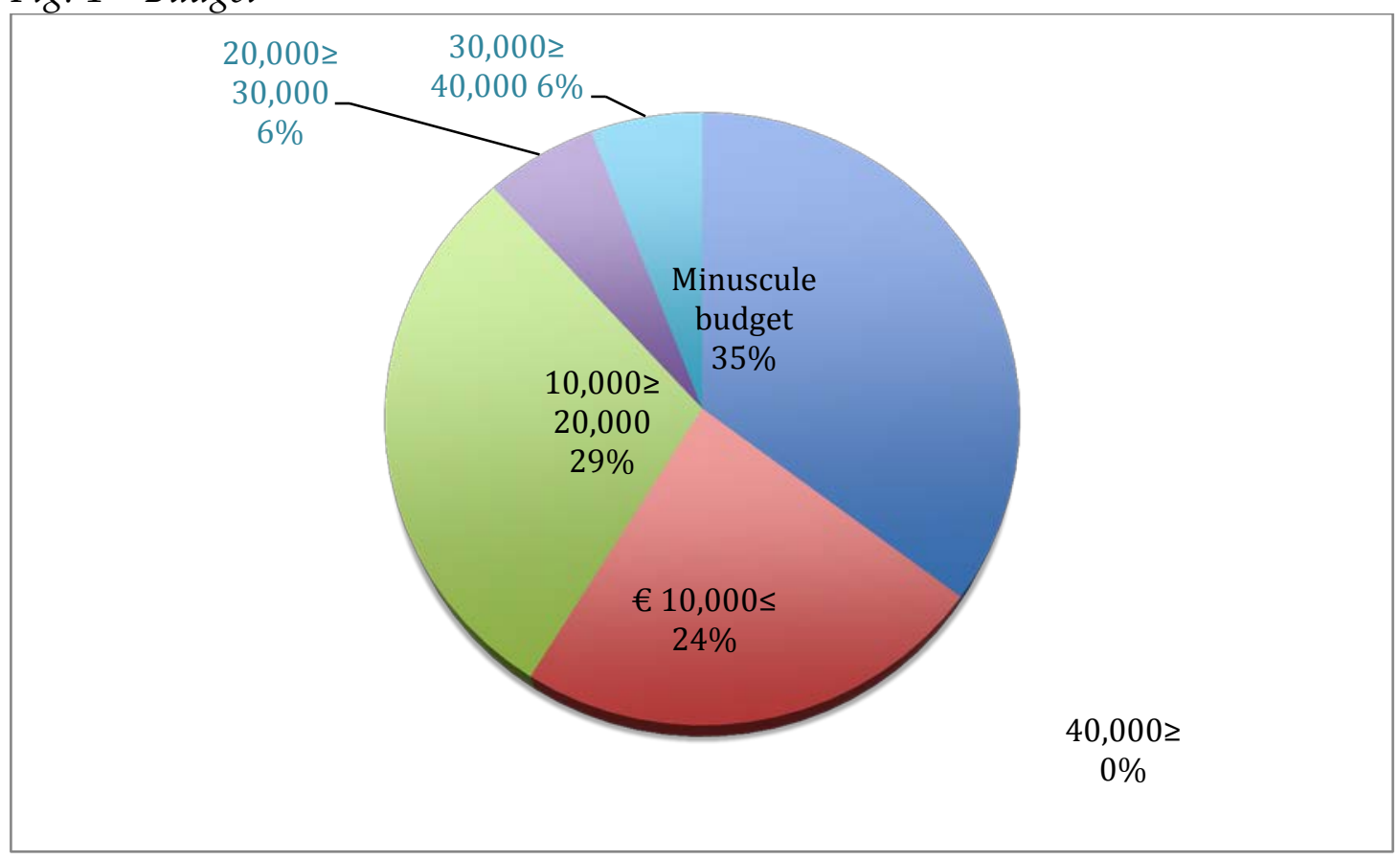

In contrast with the United States, but in common with most of Europe, in Italy a clinical teacher does not have a peculiar professional profile and there is not an allocated budget of Law Faculties. In this respect it is very interesting to consider the explanation given by Ulrich Stege: «In contrast with continental Europe, legal clinics in the U.S. system of legal education traditionally play an important role. Clinical methodology is deeply rooted in a teaching philosophy based on "learning by doing." If we add to that the fact that legal education in U.S. law school lasts for three years and that in this short period of time students have to learn both theory and practice because there is no mandatory apprenticeship during which they prepare for practice, it is quite understandable why clinics play such an important role in the U.S. system of legal education and why they are still marginal in a number of continental European countries». ${ }^{4}$

Moreover, cuts in Education, the really low level of public and private investment for research and the debt exposure of many Universities in Italy make the daily survival of these clinics more difficult. The scholars who work at a law clinic offer an additional service, generally without any economic bonus. It is not uncommon for the professor to use funds earmarked for his or her research to allow a clinic to survive. The precarious

\footnotetext{
${ }^{4}$ U. Stege, Evidence of Successes and Challenges in Clinical Legal Education in Europe, quoted.
} 
staff involved in academic jobs, meaning with a short contract or even without one at all, often work in the clinic for no pay.

Those who have funds for their activities generally utilize the University's money. 8 clinics out of 21 integrate their budget with donations from private foundations and institutions, mainly Open Society, but this is not the only one (fig. 5). The other forms of income are residuals, but it could also be promising to compete for European and international grants, also because this promotes supranational networking.

Fig. 5 - Where do the funds come from?

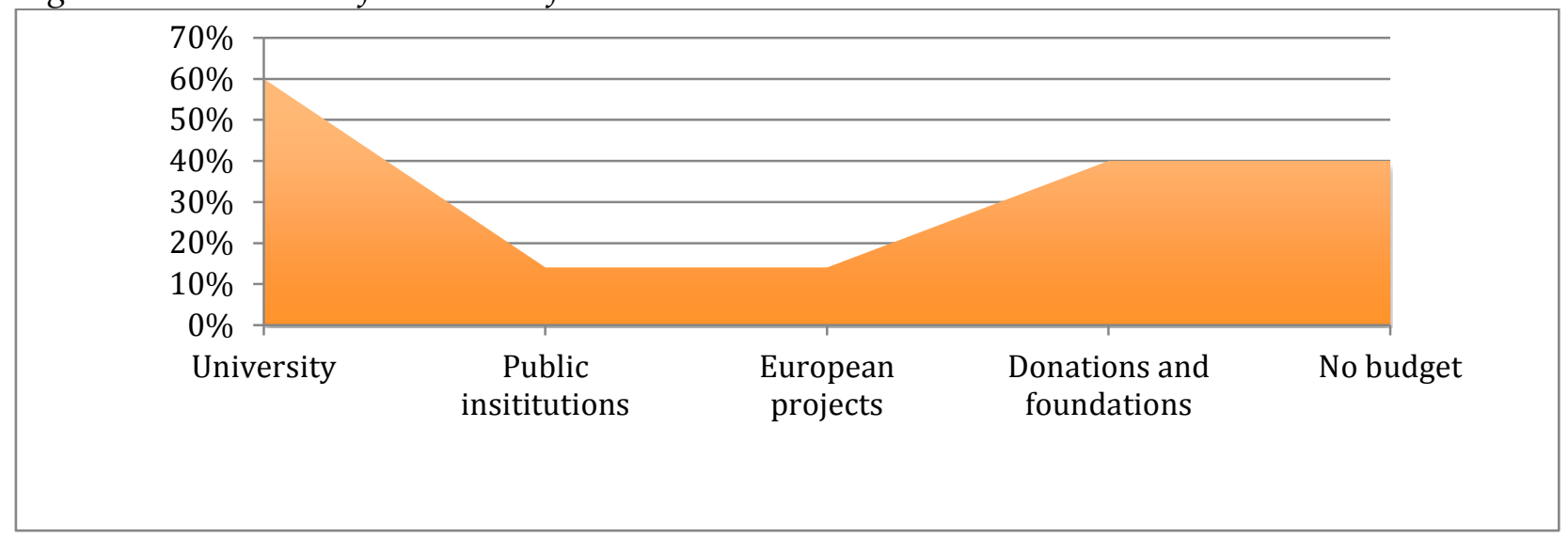

Nearly all the respondents wish to compete for European Union grants with a project related with clinical education. But most of them did not find the right call. 7 clinics out of 21 applied but only 3 were successful (fig. 6). Although until now, few clinical projects with a European partnership were approved, going forward we can expect an improvement in the economic situation if the Italian clinics enhance their fundraising skills, identify the most appropriate measures among Union projects and join in a more proactive national and international network able to plan and achieve more ambitious goals.

\section{EDUCATIONAL ASPECTS}

The relatively "senior" clinics involve a good quantity of youth in training, the vast majority are law students, but there is a significant number enrolled in other faculties, furthermore graduates, $\mathrm{PhD}$ students and post-docs participate in clinical activities too. 
This would seem to suggest a capability both to face the clients' situation with an interdisciplinary approach and also to gain and keep students after their degree.

Clinical legal education in Italy is lacking institutionalization, therefore each project must find its own modus operandi and its peculiar solution to stay in the official curricula. So, clinical experience assumes many forms in the different universities, it can be: a) a short seminary with credits; b) one of the optional classes required to complete the path for the degree; c) a way to fulfil the compulsory training or a part of the internship period required to became a lawyer ${ }^{5}$;) a post-degree course; e) voluntary work (fig. 7).

Fig. 7 - Benefit for students enrolled into clinical activities

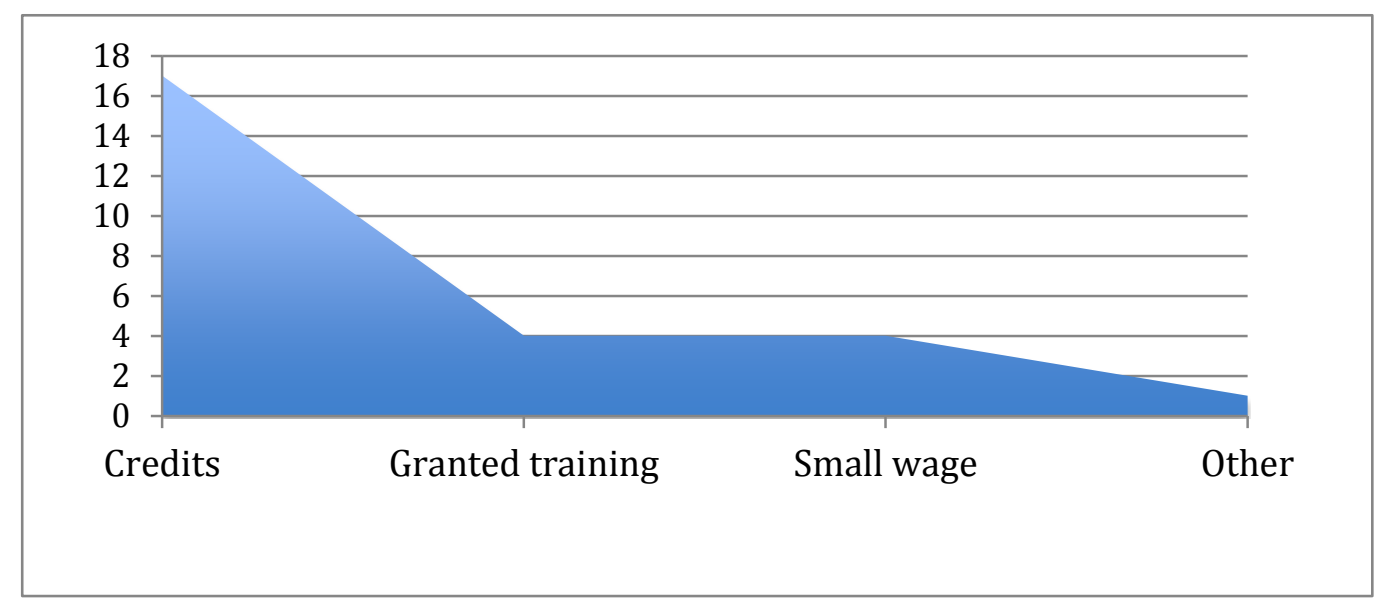

Due to the variety of ways in which clinical education is offered in the different Universities, the number of credits and the required hours differ a lot: we start with a short course of only 10 hours to a long term one of 300 hours. Anyway, the average is $40 / 50$ hours corresponding to some 6 credits. Of course the time officially scheduled is usually less than the real time taken up in the clinical work. So the credits normally underestimate students' and teachers' commitment. For this reason participating in a legal clinic needs a strong motivation and it is never compelled. It is also worth mentioning that 4 clinics give a small wage or scholarships to the students more engaged in the law clinic's management.

\footnotetext{
5 The law n. 247 of 31st December 2012, Title IV, c. I ("professional training"), art. 40 establishes that law faculties, in partnership with the bar, have to offer students the opportunity to do 6 months out of 18 of the compelled internship before the degree. Usually the student does the internship in law firm without any Academic relation, but in some Universities the clinical experience is considered valid as pre-degree internship.
} 
Probably there is an overabundance of clinical education paths, because this is a very new phenomenon, there is an absence of funds, standards and norms ruling this sector of legal training, it lacks a settled habit or a strengthened model to follow. On the other hand the Italian clinics show a high level of creativity and experimentation. Each work team although it has to tackle many obstacles and the tight budgetary situation - builds operative models focusing on the local specificity and optimising the staff's competences. It needs to be pointed out that, despite the variety of organizational patterns, the educational methodology is what is shared among all the Italian law clinics. The directors of the older clinics like the spokespersons for the fledgling ones aim to give precedence to an interactive teaching. In fact, none utilize initial lectures largely, but instead they use more activities such as role-playing games, brainstorming, case by case, videos, meetings with the protagonists of the issues addressed, lessons in contexts outside the university, and of course above all participation in the resolution of real cases in collaboration with lawyers (fig. 8).

Fig. 8 - Learning experiences proposed

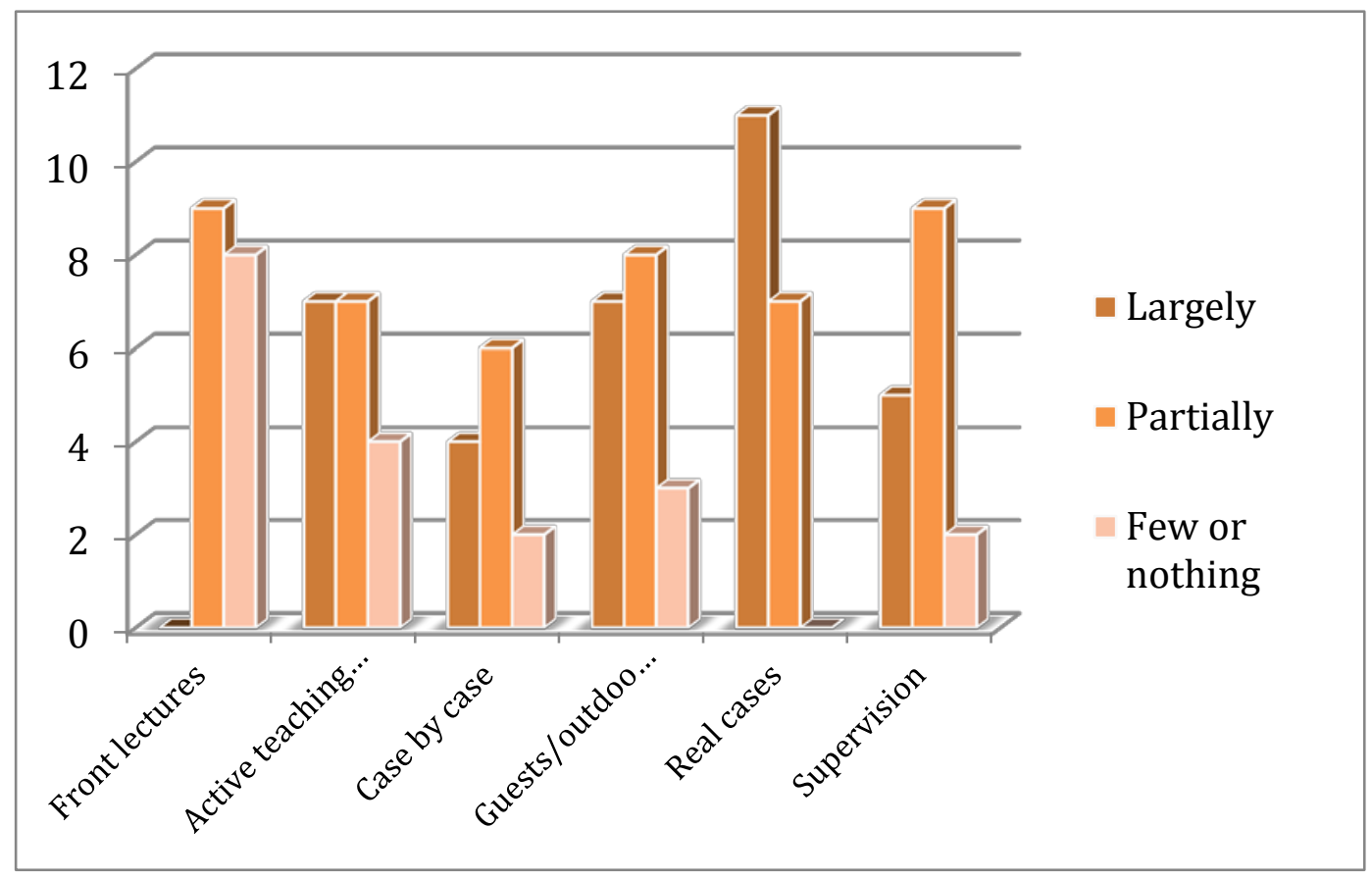


In this section, the last question aimed to gauge points of view about the impact on students of the involvement in clinical activities. More than half of respondents were shown to be very optimistic, asserting that this experience grew both professional chances and ethical responsiveness. Four clinics admitted that they could not foretell the implications on students' life due to a lack of data. $15 \%$ believed this form of education definitely permits human development, but because of the dramatic unemployment crisis of the country they cannot assume a rise of professional opportunities. Only two clinics trust in a greater employability, without a certain moral development. It is no accident that one of those is the only clinic specialized in company and banking law. That is certainly the only one not committed to the social justice mission. As in some American law schools, it sees the clinical activity more as an effective teaching method rather than an opportunity to aid vulnerable people and to act in the public interest.

Fig. 9 - Opinions on the impact of clinical experience for the students

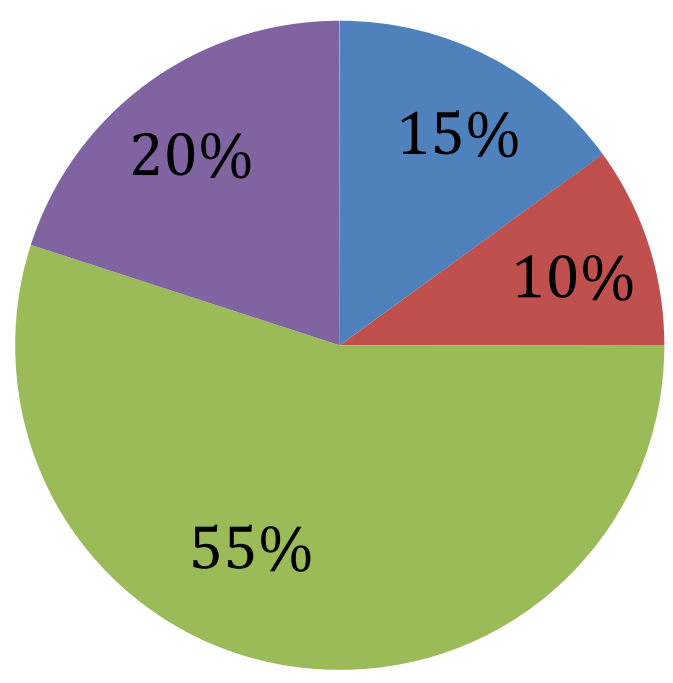

There is certainly an impact for the human development of the student, but not necessarily greater employability

- They acquire more skills and opportunities in the professional field, but not necessarily more ethical sensitivity

$\square$ Students acquire both professional opportunities and a commitment to social justice

- There aren't enough data to detect 


\section{5. $\quad$ AREAS OF INTERVENTION AND TYPES OF "CLIENTS"}

As I warned with the results of the last question in the previous paragraph - monitoring the areas of intervention and the types of clients - it is evident that almost all the Italian clinics have a strong vocation for social justice. In fact they propose a legal training through the methodology of learning by doing, but also they aim to deconstruct the University as an aseptic fortress, an ivory tower of "navel-gazing" theory afraid to engage with harsh reality. Scholars who decide to become involved in a legal clinic generally undergo the alienation and the feeling of uselessness that can sometimes go with academic work. For this reason they consider essential a civic commitment of cultural institutions.

So, it is no wonder that areas of intervention where the Italian clinics are more dynamic are: migration and asylum, detention, antidiscrimination and human rights (fig. 9).

Fig. 9 - Areas of intervention

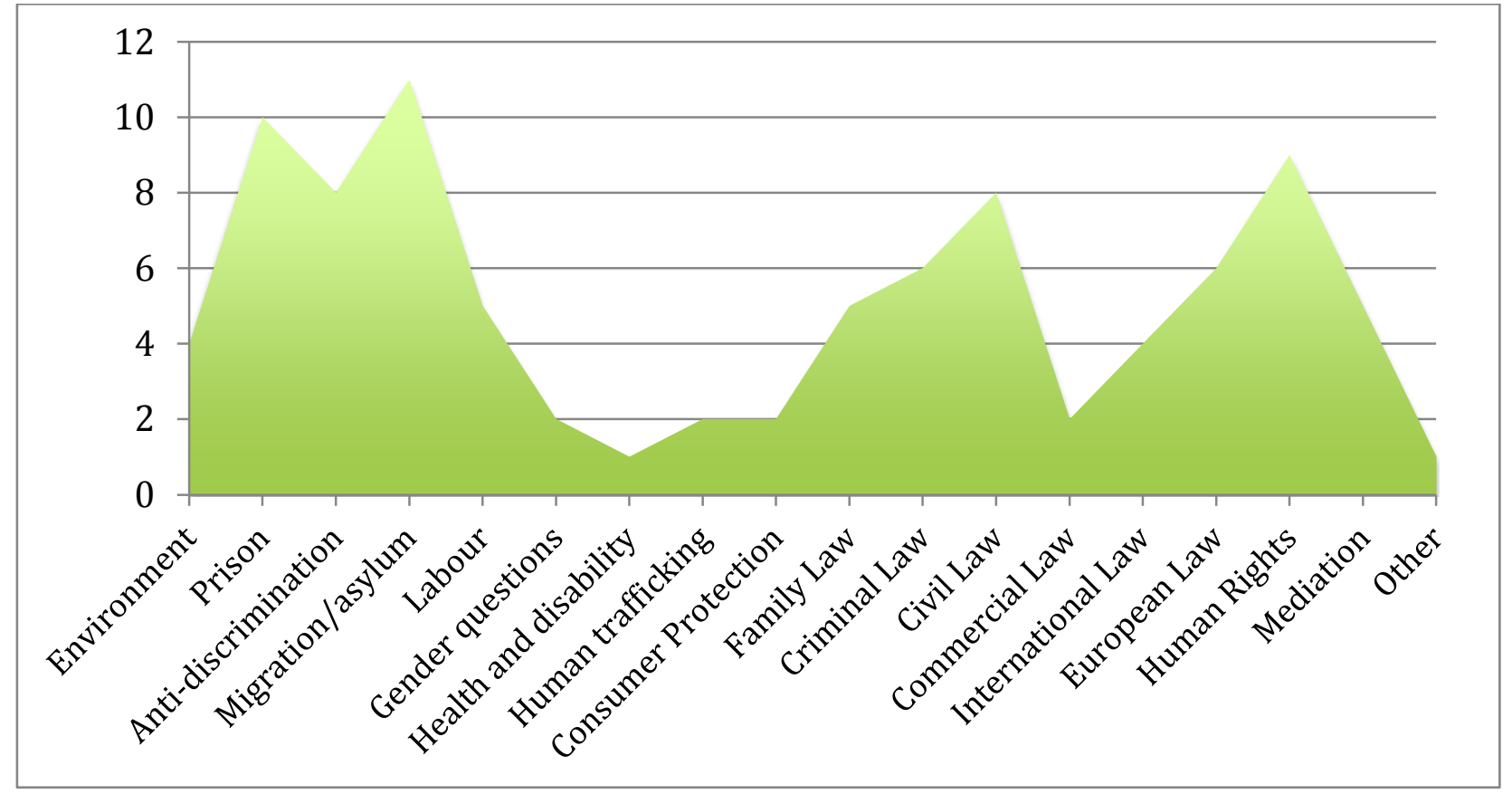

Consistent with the declared areas of intervention, the clients belong to different vulnerable categories such as: indigents and marginalised persons, prisoners, migrants, Romas, asylum seekers and refugees, but also associations working for human rights and environment (Save the Children, Caritas, Asgi, WWF, etc.) (fig. 10). 
Fig. $10-$ Clients

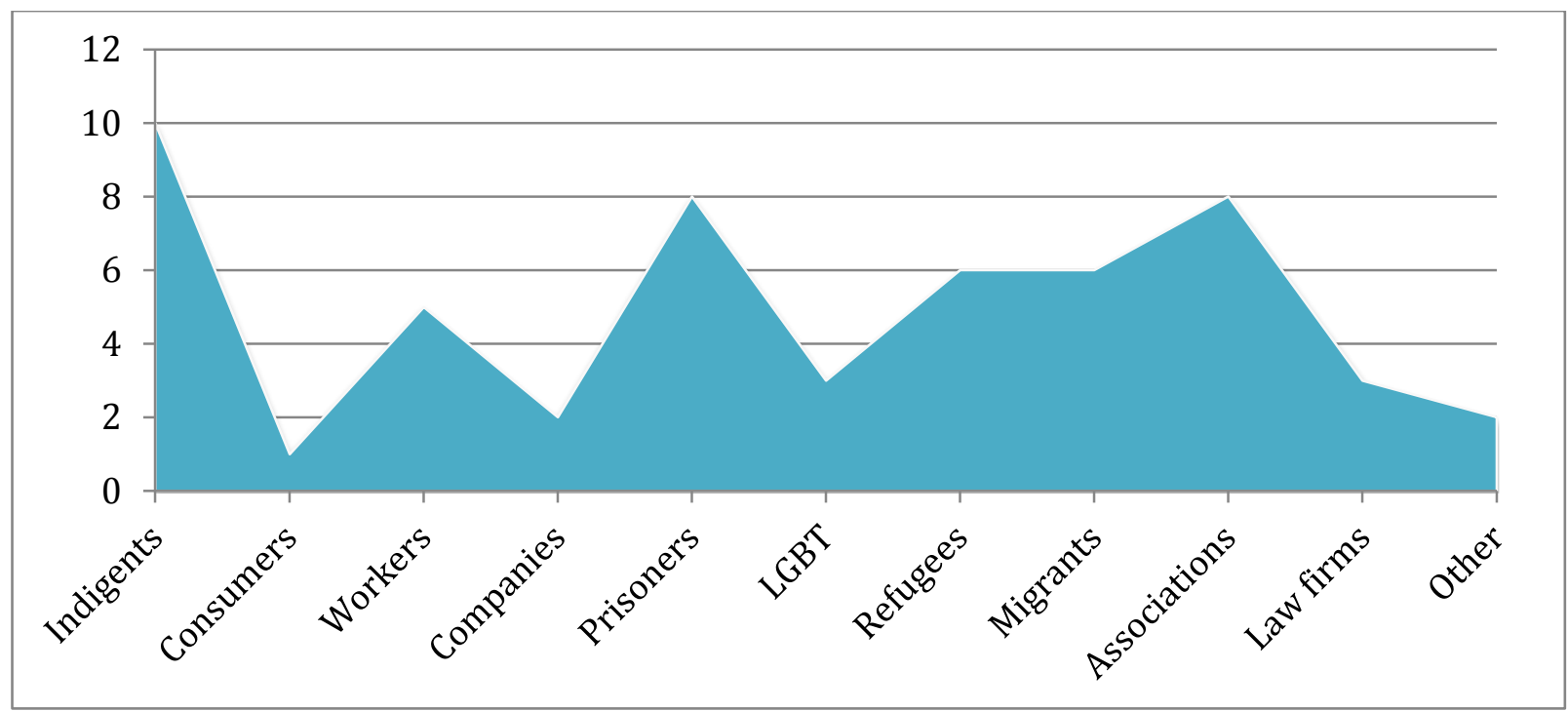

The main activity that Italian clinics propose to students is litigation in collaboration with lawyers. At the same time, delivering legal advice in-house to live-clients is very frequent too, both directly for persons in need and indirectly via associations, insitutions and law firms. 8 clinics have carried out monitoring projects and 7 declare doing street law. Although only 4 clinics attend to production of law drafts, reviewing of regulations and design of innovative policy (fig. 11) I believe that is a very promising pursuit. In this case, in fact, the clinic performs as a think tank specialized in law for social justice, the peculiar research capacity of the Academy is acknowledged and optimized and it makes the jurist's role wider and his commitment more proactive.

Fig. $11-$ Activities

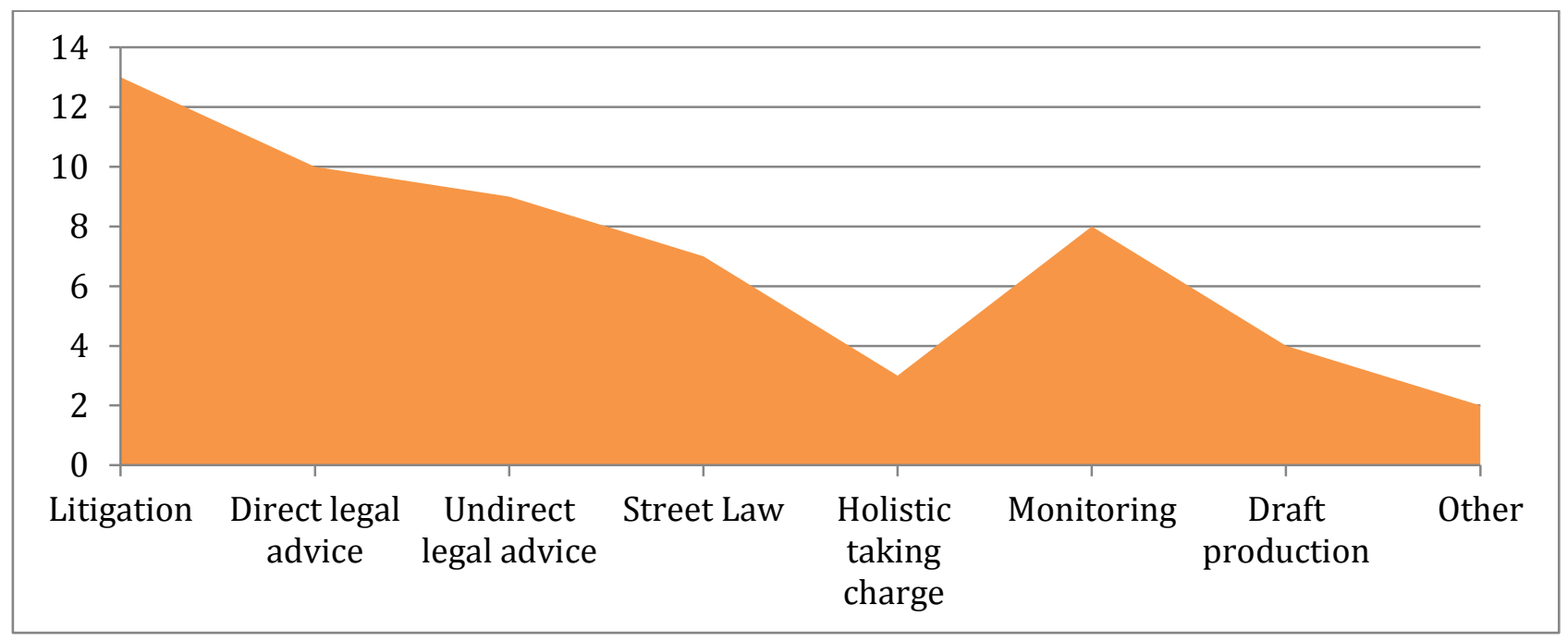




\section{EUROPEAN RELEVANCE}

The relevance of European Law in the Italian clinics' daily work is significant, even if it could be more propelled: it results low for 34\%; medium for 19\% and high for $48 \%$ (fig. 13).

Fig. 12 - Relevance of the European Law in the clinical activities on a scale of 1 to 5

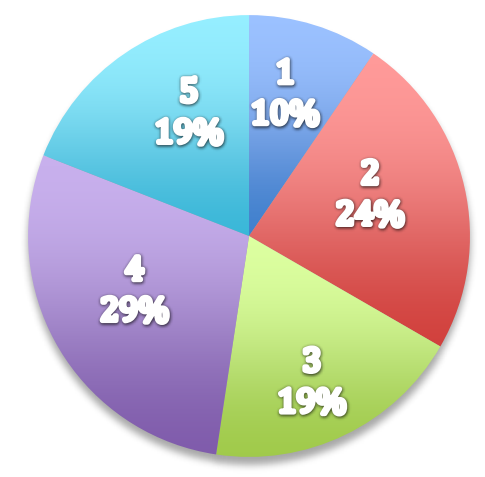

Lamin Kadhar, in a good paper titled Why the EU should take note of Europe's newest legal clinics, says: "studies consistently show that people residing in the EU (especially members of marginalized groups) face considerable obstacles in accessing their EU law rights. There seems to be both a knowledge gap and skills gap separating the people of Europe and their EU law rights. [...] The knowledge gap amongst individual rights-holders is exacerbated by a skills gap within the legal profession. Although there are increasingly more EU law specialists, their services are expensive and they are often unwilling to take on unprofitable, simple and run-of-the-mill EU law queries. Beyond this group of specialists, most domestic lawyers avoid the vast and seemingly exponentially increasing body of EU law". ${ }^{6}$ After this analysis the author presents the movement for clinical education as a good opportunity to improve human rights in Europe, through the training of a new generation of lawyers more socially conscious and more skilled in EU law.

${ }^{6}$ L. Kadhar, Why the EU should take note of Europe's newest legal clinics, in www.encle.eu, 2014. 
Developing a vision of the possible role of clinical education on the European stage is particularly important and urgent in an on-going process of institutionalization and definition of standards, where the mission is partially still open.

Starting from and expanding Khadar's proposal, in the survey I have suggested five potential impacts of the clinics in the EU context on human rights protection: a) to contribute to the formation of a new generation of attorneys/lawyers who are EU law experts; b) to enhance the access of disadvantaged people to rights guaranteed by EU legislation by providing opportunities for pro bono legal advice given by clinics; c) to produce advanced and authoritative case law/doctrines, thanks to research carried out in universities, which will push institutions and European justice towards a growing commitment to human rights protection; d) to collaborate on the production of draft regulations and policies to implement the protection of fundamental rights at the European and international level; e) to create a venue which provides free legal advice outside courts for marginalised people.

They are entirely approved by almost all the respondents.

\section{NETWORK AND MOVEMENT}

One of the most relevant aspects of legal education is being open to the external world, developing collaborations with subjects out of the academic orbit. So, in order to have a more comprehensive overview, it has been necessary inquiring clinics' partnership.

The data indicates that all clinics have formal or informal relationships with lawyers and law firms. With the Bar association 5 clinics are said to be on good terms, 6 act fully independently, while the others do not respond or state that they should improve the relation.

$75 \%$ of clinics (all the established ones plus some in the pilot phase) collaborate with institutions, mostly by memoranda of understanding or similar formal agreements. Among these there are prison admins, courts, job advisers, and so on. 
12 clinics are said to be in relationship with organizations of civil society at the national level and 6 of these have developed connections with associations and NGOs at European level. Among these we find Unions, NGOs working in international cooperation, groups that uphold the rights of migrants, children, prisoners and the environment (such as: Antigone, L'Altro diritto, Ciss, Asgi, Caritas, Teatro e società, Save the Children, Cospes, CGIL Torino, CUB, USB, Gruppo Abele, WWF).

With few exceptions, the network among clinics is generally good. 14 clinics declare that they are linked with other Italian clinics and 6 with European ones (fig. 11). Although in my opinion this result underestimates the actual reality, because - in the months after the collection of survey data - a brisk improvement of the national network is taking place and opening more chances of dialogue with ENCLE too.

Fig. 11 - Relationships with other clinics

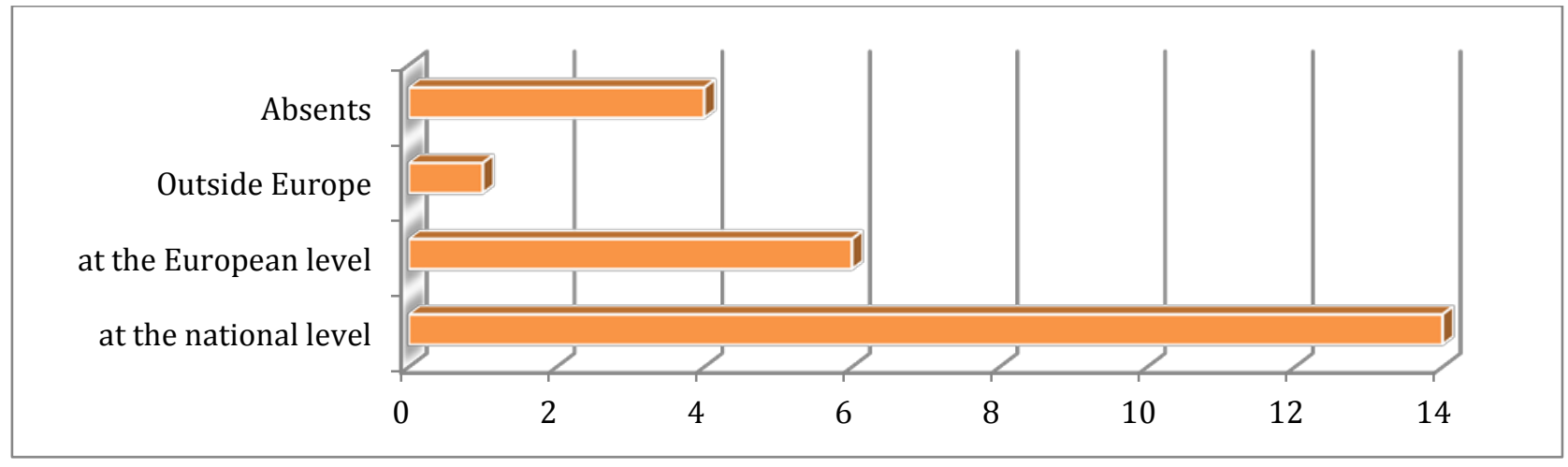

These observations seem to indicate the birth of a movement of Italian legal clinics, in fact a movement - differently from a simple network - promotes not only specific actions but its members share a vision. The impetus to enforce the connections is sprung by the pioneer clinicians in Italy, among them: Marzia Barbera of Università di Brescia, Ulrich Stege of the International University College of Turin and ENCLE, Emilio Santoro for L'altro diritto and the Università di Firenze and Enrica Rigo for Università di Rome Tre. But they were also able to involve the younger and fledgling projects. In fact at each network meeting the number of participants increases. 
People acting within the University in the social justice field and with an approach similar to clinicians are joining in this young movement, even if they do not yet have the proper status of a clinic. They manifest a civic and, in a broader sense, political attitude, they often feel like a minority in their faculty, needing recognition in a larger group, that gives name and acknowledgment to their idea of legal education and the jurist's role in society.

The issues most discussed are the definition of the identity profile of a legal clinic and its mandate, the ways to enforce clinical education ensuring more institutionalization and a broader recognition within the University curricula, and evaluation of possible strategies to guarantee the sustainability of the related projects.

In this respect I asked which policies could empower the clinics. All the respondents have stressed the need to improve funding, many consider important strengthening networking and exchange between clinics, also a good number believe it is important to reward the universities that activate legal clinics. 6 out of 21 consider it a good idea to make legal education mandatory within law faculties and only 5 think it useful to establish quality standards (fig. 14).

Fig. 12 - How to enhance the role of legal clinics

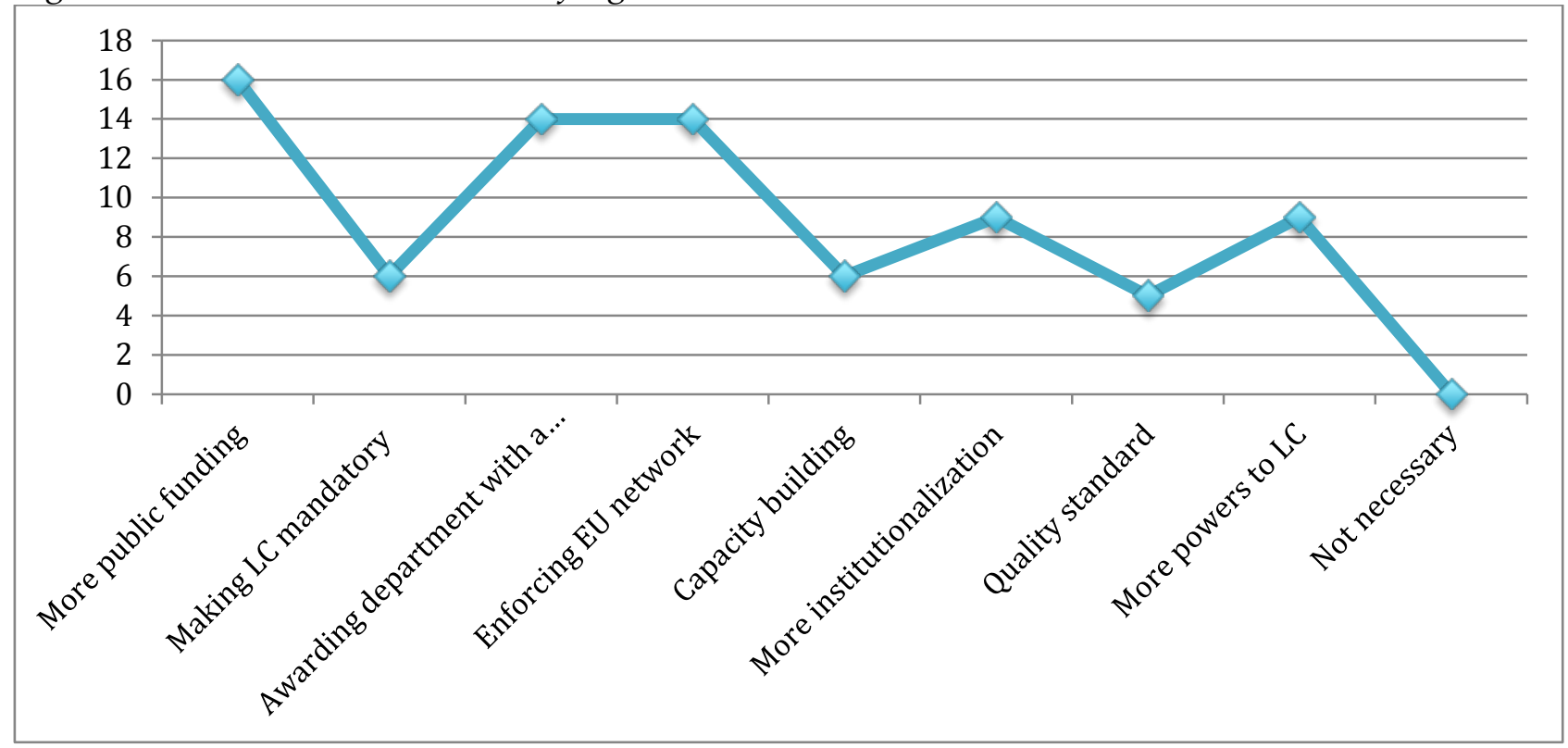

Despite the variety of opinions, all the participants in this movement wish to keep the pedagogic mission and the pursuit of social justice together. In fact to the question about mission only one clinic has answered that its only commitment is professional training, 
without any necessary involvement with ethics or social work. But this clinic acts independently without participating in the network meetings and discussions.

At present, the movement does not have any formal status. But I have to mention the recent birth of an inter-departmental centre with the goal of creating a legal clinic in any associated department, if there is not one already, and developing a synergy among all the members. This Centre connects the Universities of Bari, Turin, Salerno, Naples, Cosenza, Palermo, Pisa, Rome and Florence and is specialized in human rights, migration, marginality and detention.

The emergence of such a movement could influence the professional culture of Italian lawyers. The students enrolled in the clinics' activities have the opportunity to experiment with the law in action, to use their legal competence for rights, equity and public interest; they meet people who rarely arrive in a law firm due to their economic or social condition. So, they usually declare that they have been very affected by clinical experience and claim to have acquired more awareness and even a different sensitivity.

Of course these young people are much less than the totality of law students, and the scholars involved are a very small part of the faculty staff, but they can play what Serge Moscovici calls the minority influence": "Our results support the notion that majority and minority influence are different processes, the former producing mostly public submissiveness without private acceptance, and the latter producing primarily changes in private responses. These processes, called compliance and conversion, are mutually exclusive and to a certain extent, opposite" ${ }^{8}$. This means that the Italian movement probably cannot become mainstream and enrol the mass of students and scholars, but it can nonetheless have a deeper effect through changing a little the vision and also the attitude of those jurists who will never become clinicians.

\footnotetext{
7 S. Moscovici, Social influence and social change, Academic Press, London, 1976.

${ }^{8}$ S. Moscovici, B. Personnaz, Minority influence and Conversion Beahviour in a Perceptual Task, in «Journal of experimental social psychology», n. 16, (1980) p. 280.
} 